Effectiveness of coconut fibre media in biological wastewater treatment for rubber factory effluent

by

Kudaligama Vithanage Vidya Sagari Kudaligama

Thesis submitted to the

University of Sri Jayawardenapura

for the award of the

Degree of Master of Philosophy in Botany

2004 


\section{DECLERATION BY AUTHOR}

The work described in this thesis was carried out by me under the supervision of Mr. W. M. Thurul, Thurul Safe Environment, Chilaw Road, Nainamadama, Prof. P. A. J. Yapa, Senior Lecturer, Uni. of Sri Jayawardenapura, Nugegoda and Dr. C. K. Jayasinghe, Deputy Director Research, Rubber Research Institute, Dartonfield, Agalawatta and a report on this has not been submitted in whole or in part to any University or any other institution for another Degree/Diploma.

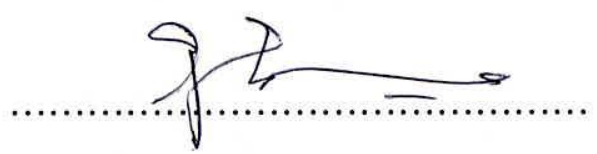

K.V.V.S.Kudaligama 


\section{DECLERATION BY SUPERVISORS}

"We certify that the above statement made by the candidate is true and this thesis is suitable for submission to the University for the purpose of evaluation"

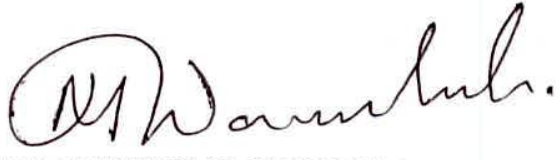

Mr. W. M. Thurul,

Thurul Safe Environment,

Research \& Development Implementation Bureau,

Chilaw Road,

Nainamadama

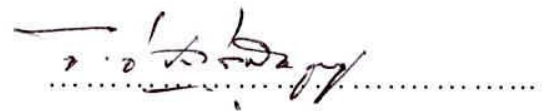

Prof. P. A. J. Yapa,

Senior Lecturer,

Uni. of Sri Jayawardenapura,

Nugegoda

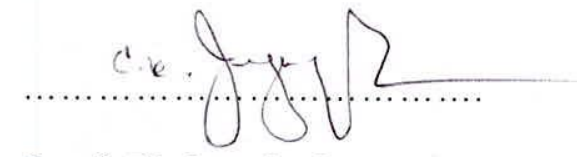

Dr. C. K. Jayasinghe,

Deputy Director Research,

Rubber Research Institute of Sri Lank

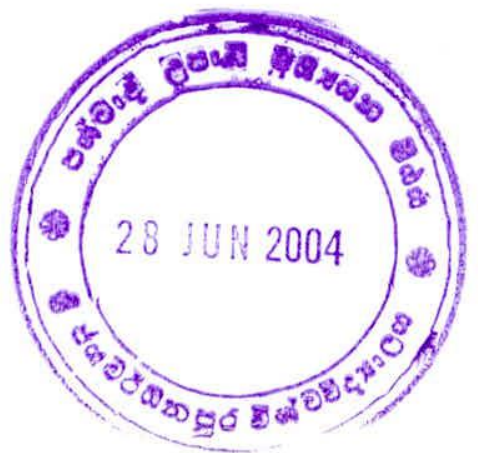

Dartonfield,

Agalawatta

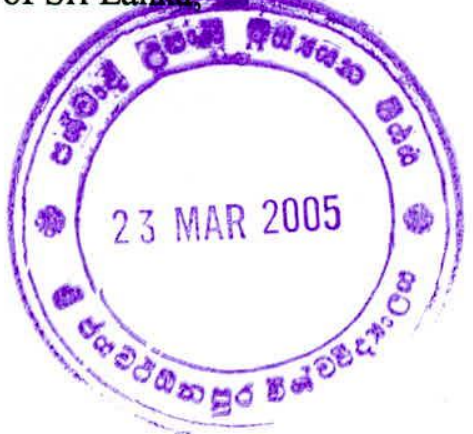


Dedicated to my loving parents,

Saminda and Kavindu 
Page No.

LIST OF FIGURES

LIST OF TABLES

IV

ACKNOWLEDGMENT

VII

ABREVIATIONS

VIII

ABSTRACT

IX

1

INTRODUCTON

\section{1}

REVIEW OF LITERATURE 6

$\begin{array}{lll}2.1 & \text { Raw Rubber production and waste generation }\end{array}$

$\begin{array}{lll}2.1 .1 & \text { Latex crepe Industry }\end{array}$

2.1.2 Latex concentrate Industry 9

2.1.3 Ribbed smoked sheet (RSS) Industry 11

$\begin{array}{lll}2.2 & \text { Biological wastewater treatment } & 12\end{array}$

$\begin{array}{lll}2.2 .1 & \text { Aerobic treatment } & 13\end{array}$

$\begin{array}{lll}\text { 2.2.2 Anaerobic treatment } & 14\end{array}$

2.2.2.1 Microbiology and biochemistry of anaerobic treatment $\quad 14$

2.3 Stationary media in biological wastewater treatment 19

2.3.1 Coir fibre as a stationary media in wastewater treatment 22

$\begin{array}{lll}2.3 .1 .1 & \text { Coir fibre } & 23\end{array}$

$\begin{array}{lll}\text { 2.3.2 Bio-Brush media } & 24\end{array}$

2.3.2.1 Preparation of Bio-brush media 24

2.3.2.2 Features of Bio-brush media 25 
$\begin{array}{lll}2.4 .1 & \text { Anaerobic processes } & 27\end{array}$

$\begin{array}{lll}2.4 .1 .1 & \text { Anaerobic filters (AF) } & 30\end{array}$

2.4.1.2 Covered Activated Ditch (CAD) system 35

$\begin{array}{lll}\text { 2.4.1.3 Anaerobic pond/lagoon process } & 36\end{array}$

$\begin{array}{lll}\text { 2.4.1.4 Other anaerobic unit processes } & 38\end{array}$

2.5 Raw rubber factory wastewater management 39

2.5.1 Biological treatment methods $\quad 39$

2.5.2 Other management possibilities 42

3 MATERIALS AND METHODS $\quad 44$

$3.1 \quad$ Test reactor designing $\quad 44$

3.1.1 Designing of Bio-brush media 44

3.1.1.1 Approximate specific surface area (SSA) of coir fibre 44

3.1.1.2 Preparation of Bio-brush 44

$\begin{array}{lll}\text { 3.1.2 Civil work of test reactors } & 47\end{array}$

3.1.3 Preparation of anaerobic seed sludge $\quad 50$

$\begin{array}{ll}\text { 3.1.4 Start-up of reactors } & 50\end{array}$

3.1.5 Feed characteristics and organic loading 51

3.2 Experimental work $\quad 51$

3.2.2 Effect of different combinations of SSAs diameters and OLRs on 51 rubber factory effluent treatment

3.2.2.1 The temporal behaviour of the COD removal efficiency 53

3.2.2.2 The COD removal efficiency at maturation of test reactors 53 
3.2.3 Effect of inorganic nutrients (nitrogen) and processing chemicals

on rubber factory effluent treatment

3.2.3.1 Nitrogen content of effluent

3.2.3.2 Chemicals, used during processing 55

3.2.4 Variation of chemical and microbiological parameters $\quad 56$

3.2.4.1 $\mathrm{pH}$ of test reactors $\quad 56$

3.2.4.2 Suspended solids (SS) content of effluent 56

$\begin{array}{llr}3.3 & \mathbf{5 6}\end{array}$

3.3.1 Chemical Oxygen Demand (COD) 56

$\begin{array}{lll}3.3 .2 & \mathrm{pH} & 57\end{array}$

$\begin{array}{lll}\text { 3.3.3 Suspended solids content } & 57\end{array}$

$\begin{array}{lll}\text { 3.3.4 Total nitrogen content } & 57\end{array}$

$4 \quad$ RESULTS $\quad 58$

4.1 Effect of different combinations of specific surface areas (SSAs), 58 diameters under different organic loading rates (OLRs) on rubber factory effluent treatment

4.1.1 Temporal behaviour of COD removal efficiency of combination I 58

4.1.1.1 $0.5 \mathrm{COD} \mathrm{kg} / \mathrm{m}^{3} / \mathrm{d}$ organic loading rate $\quad 59$

4.1.1.2 1.0 COD kg $/ \mathrm{m}^{3} / \mathrm{d}$ organic loading rate $\quad 61$

4.1.1.3 2.5 COD kg $/ \mathrm{m}^{3} / \mathrm{d}$ organic loading rate 63

4.1.1.4 3.5 COD kg $/ \mathrm{m}^{3} / \mathrm{d}$ organic loading rate $\quad 65$

4.1.2 Temporal behaviour of COD removal efficiency of combination II 68

4.1.2.1 $\quad 0.5 \mathrm{COD} \mathrm{kg} / \mathrm{m}^{3} / \mathrm{d}$ organic loading rate. $\quad 68$

4.1.2.2 $1.0 \mathrm{COD} \mathrm{kg} / \mathrm{m}^{3} / \mathrm{d}$ organic loading rate $\quad 70$ 
4.1.2.3 2.5 COD kg $/ \mathrm{m}^{3} / \mathrm{d}$ organic loading rate 72

4.1.2.4 3.5 COD kg $/ \mathrm{m}^{3} / \mathrm{d}$ organic loading rate $\quad 74$

4.1.3 Temporal behaviour of COD removal efficiency of combination III 77

$\begin{array}{lll}\text { 4.1.3.1 } & 0.5 \mathrm{COD} \mathrm{kg} / \mathrm{m}^{3} / \mathrm{d} \text { organic loading rate } & 77\end{array}$

4.1.3.2 $1.0 \mathrm{COD} \mathrm{kg} / \mathrm{m}^{3} / \mathrm{d}$ organic loading rate $\quad 79$

4.1.3.3 2.5 COD kg $/ \mathrm{m}^{3} / \mathrm{d}$ organic loading rate 81

4.1.3.4 $3.5 \mathrm{COD} \mathrm{kg} / \mathrm{m}^{3} / \mathrm{d}$ organic loading rate 83

4.1.4 The COD removal efficiency at maturation of test reactors 85

4.1.4.1 Effect of $10 \mathrm{~cm}$ diameter Bio-brush media under different SSAs 85

4.1.4.2 Effect of $10 \mathrm{~cm}$ diameter Bio-brush media under different OLRs 87

4.1.4.3 Effect of $15 \mathrm{~cm}$ diameter Bio-brush media under different SSAs 90

4.1.4.4 Effect of $15 \mathrm{~cm}$ diameter Bio-brush media under different OLRs 92

4.1.4.5 Effect of $100 \mathrm{~m}^{2} / \mathrm{m}^{3} \mathrm{SSA}$ of Bio-brush media under different 94 diameters

4.1.4.6 Effect of $100 \mathrm{~m}^{2} / \mathrm{m}^{3} \mathrm{SSA}$ of Bio-brush media under different OLRs 96

$\begin{array}{lll}\text { 4.1.5 Summary of COD removal efficiency } & 98\end{array}$

$\begin{array}{lll}4.2 & \text { Effect of inorganic nutrients (nitrogen) and processing } & 100\end{array}$ chemicals on rubber factory effluent treatment

$\begin{array}{ll}\text { 4.2.1 Nitrogen content of effluent } & 100\end{array}$

$\begin{array}{lll}\text { 4.2.2 Chemicals used during processing } & 102\end{array}$

4.3 Variation of chemical and microbiological parameters 104

$\begin{array}{lll}\text { 4.3.1 } & \mathrm{pH} \text { of test reactor } & 104\end{array}$

4.3.2 Suspended solids content of effluent 106

$\begin{array}{llr}5 & 108\end{array}$ 
6 CONCLUSION 118

7 LITERATURE CITED 119

8 LIST OF PUBLICATIONS 129

9 APENDICES 130 


\section{LIST OF FIGURES}

Page No.

Fig. 1 Flow diagram for waste generation in latex crepe industry (Anon, 1992b) 7

Fig. 2 Flow diagram for waste generation in latex concentrate industry (Anon, 9 1992c)

Fig. 3 Flow diagram for waste generation in RSS industry (Anon, 1992b) 12

Fig. 4 Metabolic steps and microbial groups involved in anaerobic digestion $\quad 15$

Fig. 5 Different types of media used in wastewater treatment systems 21

$\begin{array}{lll}\text { Fig. } 6 \text { Bio-brush } & 26\end{array}$

Fig. 7 Cross section of ditches showing possible arrangements of Bio-brushes 36

$\begin{array}{lll}\text { Fig. } 8 & \text { CAD treatment systems operating at different factory sites } & 37\end{array}$

Fig. 9 Bio-brushes with different SSAs of media and diameters used in test 46 reactors

Fig. 10 Schematic diagram of a test reactor $\quad 47$

Fig. 11 Flow diagram of the experimental setting 48

Fig. 12 Ditch type test reactors 49

Fig. 13 Laboratory scale $54 \mathrm{~L}$ test reactor 54

Fig. 14 COD removal efficiency of reactors with $10 \mathrm{~cm}$ diameter Bio-brush media $\quad 59$ run under $0.5 \mathrm{COD} \mathrm{kg} / \mathrm{m}^{3} / \mathrm{d}$ OLR

Fig. 15 COD removal efficiency of reactors with $10 \mathrm{~cm}$ diameter Bio-brush media 61 run under $1.0 \mathrm{COD} \mathrm{kg} / \mathrm{m}^{3} / \mathrm{d}$ OLR

Fig. 16 COD removal efficiency of reactors with $10 \mathrm{~cm}$ diameter Bio-brush media 63 run under $2.5 \mathrm{COD} \mathrm{kg} / \mathrm{m}^{3} / \mathrm{d}$ OLR

Fig. 17 COD removal efficiency of reactors with $10 \mathrm{~cm}$ diameter Bio-brush media 65 run under $3.5 \mathrm{COD} \mathrm{kg} / \mathrm{m}^{3} / \mathrm{d}$ OLR 
Fig. 18 COD removal efficiency of reactors with $15 \mathrm{~cm}$ diameter Bio-brush media run under $0.5 \mathrm{COD} \mathrm{kg} / \mathrm{m}^{3} / \mathrm{d}$ OLR.

Fig. 19 COD removal efficiency of reactors with $15 \mathrm{~cm}$ diameter Bio-brush media run under $1.0 \mathrm{COD} \mathrm{kg} / \mathrm{m}^{3} / \mathrm{d}$ OLR

Fig. 20 COD removal efficiency of reactors with $15 \mathrm{~cm}$ diameter Bio-brush media run under $2.5 \mathrm{COD} \mathrm{kg} / \mathrm{m}^{3} / \mathrm{d}$ OLR

Fig. 21 COD removal efficiency of reactors with $15 \mathrm{~cm}$ diameter Bio-brush media run under $3.5 \mathrm{COD} \mathrm{kg} / \mathrm{m}^{3} / \mathrm{d}$ OLR

Fig. 22 COD removal efficiency of reactors with $100 \mathrm{~m}^{2} / \mathrm{m}^{3}$ SSA of Bio-brush media run under $0.5 \mathrm{COD} \mathrm{kg} / \mathrm{m}^{3} / \mathrm{d}$ OLR

Fig. 23 COD removal efficiency of reactors with $100 \mathrm{~m}^{2} / \mathrm{m}^{3} \mathrm{SSA}$ of Bio-brush media run under $1.0 \mathrm{COD} \mathrm{kg} / \mathrm{m}^{3} / \mathrm{d}$ OLR

Fig. 24 COD removal efficiency of reactors with $100 \mathrm{~m}^{2} / \mathrm{m}^{3}$ SSA of Bio-brush media run under $2.5 \mathrm{COD} \mathrm{kg} / \mathrm{m}^{3} / \mathrm{d}$ OLR

Fig. 25 COD removal efficiency of reactors with $100 \mathrm{~m}^{2} / \mathrm{m}^{3} \mathrm{SSA}$ of Bio-brush media run under $3.5 \mathrm{COD} \mathrm{kg} / \mathrm{m}^{3} / \mathrm{d}$ OLR

Fig. 26 Effect of different SSAs of $10 \mathrm{~cm}$ diameter Bio-brush media on COD removal efficiency under different OLRs

Fig. 27 Effect of different OLRs on COD removal efficiency under different SSAs of media with $10 \mathrm{~cm}$ diameter of Bio-brush

Fig. 28 Effect of different SSAs of $15 \mathrm{~cm}$ diameter Bio-brush media on COD removal efficiency under different OLRs

Fig. 29 Effect of different OLRs on COD removal efficiency under different SSAs of media with $15 \mathrm{~cm}$ diameter of Bio-brush

Fig. 30 Effect of different diameters of Bio-brush media with $100 \mathrm{~m}^{2} / \mathrm{m}^{3} \mathrm{SSAs}$ 94 on COD removal efficiency under different OLR 
Fig. 31 Effect of different OLRs on COD removal efficiency under different diameters of Bio-brush media with $100 \mathrm{~m}^{2} / \mathrm{m}^{3}$ of SSA

Fig. 32 COD removal efficiency of the reactors run with normal effluent and nitrogen content corrected effluent

Fig. 33 COD removal efficiency of the reactors run with chemical free effluent and effluent with processing chemicals

Fig. $34 \mathrm{pH}$ of test reactor No 10/200 under four different OLRs

Fig. 35 Suspended solids of effluent of reactor No. 10/200 under four different OLRs

Fig. 36 Mean COD removal efficiency $(>80 \%)$ of different test reactors under different OLRs

Fig. 37 Flow chart showing overall findings for a complete biological treatment system using coconut fibre media for rubber factory effluent 


\section{LIST OF TABLES}

Page No.

Table 1 Wastewater characteristics of crepe rubber manufacturing (Anon, 1992b)

Table 2 Average composition of combined wastewater and waste loads in concentrated latex production (Anon, 1992c)

Table 3 Chemical composition of coir (Bhowmick \& Debnath, 1984)

Table 4 Typical requirements on high-rate anaerobic systems, Weiland \& Rozzi (1991)

Table 5 Benefits and limitations of an Anaerobic treatment of wastewater Lettinga et.al, (1980)

Table 6 Characteristics of AF reactors

Table 7 Specifications of Bio-brushes used in different test reactors

Table 8 Different combinations of SSAs set with 10 and $15 \mathrm{~cm}$ diameter Biobrush medium

Table 9 The combination of different diameters set under $100 \mathrm{~m}^{2} / \mathrm{m}^{3}$ SSA of

Bio-brush medium

Table 10 Different organic loads introduced

Table 11 Rate of COD rem\% of $10 \mathrm{~cm}$ diameter Bio-brush media, under 5 different SSAs at $0.5 \mathrm{COD} \mathrm{kg} / \mathrm{m}^{3} / \mathrm{d}$ OLR.

Table 12 Rate of COD rem $\%$ of $10 \mathrm{~cm}$ diameter Bio-brush media, under 5 different SSAs at $1.0 \mathrm{COD} \mathrm{kg} / \mathrm{m}^{3} / \mathrm{d}$ OLR.

Table 13 Rate of COD rem $\%$ of $10 \mathrm{~cm}$ diameter Bio-brush media, under 5 different SSAs at $2.5 \mathrm{COD} \mathrm{kg} / \mathrm{m}^{3} / \mathrm{d}$ OLR. 
Table 14 Rate of COD rem $\%$ of $10 \mathrm{~cm}$ diameter Bio-brush media, under 5 different SSAs at $3.5 \mathrm{COD} \mathrm{kg} / \mathrm{m}^{3} / \mathrm{d}$ OLR.

Table 15 Rate of COD rem $\%$ of $15 \mathrm{~cm}$ diameter Bio-brush media, under 4 different SSAs at $0.5 \mathrm{COD} \mathrm{kg} / \mathrm{m}^{3} / \mathrm{d}$ OLR.

Table 16 Rate of COD rem $\%$ of $15 \mathrm{~cm}$ diameter Bio-brush media, under 4 different SSAs at $1.0 \mathrm{COD} \mathrm{kg} / \mathrm{m}^{3} / \mathrm{d}$ OLR.

Table 17 Rate of COD rem $\%$ of $15 \mathrm{~cm}$ diameter Bio-brush media, under 4 different SSAs at $2.5 \mathrm{COD} \mathrm{kg} / \mathrm{m}^{3} / \mathrm{d}$ OLR.

Table 18 Rate of COD rem $\%$ of $15 \mathrm{~cm}$ diameter Bio-brush media, under 4 75 different SSAs at $3.5 \mathrm{COD} \mathrm{kg} / \mathrm{m}^{3} / \mathrm{d}$ OLR.

Table 19 Rate of COD rem $\%$ of reactors with $100 \mathrm{~m}^{2} / \mathrm{m}^{3}$ SSA of Bio-brush media run under $0.5 \mathrm{COD} \mathrm{kg} / \mathrm{m}^{3} / \mathrm{d}$ OLR.

Table 20 Rate of COD rem $\%$ of reactors with $100 \mathrm{~m}^{2} / \mathrm{m}^{3} \mathrm{~S}$ of Bio-brush media

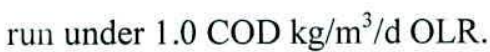

Table 21 Rate of COD rem $\%$ of reactors with $100 \mathrm{~m}^{2} / \mathrm{m}^{3}$ SSA of Bio-brush media run under $2.5 \mathrm{COD} \mathrm{kg} / \mathrm{m}^{3} / \mathrm{d}$ OLR.

Table 22 Rate of COD rem\% of reactors with $100 \mathrm{~m}^{2} / \mathrm{m}^{3}$ SSA of Bio-brush media run under $3.5 \mathrm{COD} \mathrm{kg} / \mathrm{m}^{3} / \mathrm{d}$ OLR.

Table 23 Comparison of mean COD rem\% for different OLRs for fixed SSA with $10 \mathrm{~cm}$ diameter Bio-brush media

Table 24 Comparison of mean COD rem $\%$ for different SSA with $10 \mathrm{~cm}$ diameter Bio-brush media for fixed OLRs

Table 25 Comparison of mean COD rem $\%$ for different OLRs for fixed SSA 91 with $15 \mathrm{~cm}$ diameter Bio-brush media

Table 26 Comparison of mean COD rem $\%$ for different SSA with $15 \mathrm{~cm}$ 93 diameter Bio-brush media for fixed OLRs 
Table 27 Comparison of mean COD rem $\%$ for different OLRs for fixed diameter of Bio-brush media with $100 \mathrm{~m}^{2} / \mathrm{m}^{3} \mathrm{SSA}$

Table 28 Comparison of mean COD rem\% for different diameters of Bio-brush media with $100 \mathrm{~m}^{2} / \mathrm{m}^{3} \mathrm{SSA}$ for fixed OLRs

Table 29 Summary of COD removal efficiency 


\section{ACKNOWELEDGEMENT}

The valuable guidance and advice of Mr M.T Warnakula, Prof. P.A.J.Yapa and Dr. C. K. Jayasinghe as supervisors throughout this study is greatly acknowledged.

I am very much grateful to Dr. L.M.K Tillekeratne, Director, RRISL, and the members of RRB for granting me permission for carrying out this project.

Thanks are also due to Mrs. W. Wijesuriya for statistical analysis and also the guidance and the encouragement given by her during the study is greatly appreciated.

I wish to record my special thanks to Mr. W. Amarathunga for photographing, Mrs. P. Amarasekera for word processing, Mrs Ramani Amarathunga for helping in literature surveying and Mr Upali Kannangara for helping in preparing the manuscript.

I wish to express my sincere thanks to Mrs. G.V.L. Nilmini, Mr. P.D.J. Rodrigo, Mr. D. Ramawikrama and Mr. W Kulathunga of Biochemistry Department, RRISL, for their continuous support during the study. The help of Dr. Priyanthi, Sarojini,Vidura and Priyantha is also gratefully acknowledged.

Finally, I am very grateful to my parents and Saminda for their encouragement and moral support during the study. 


\section{ABREVIATIONS}

$\mathrm{AF}$

BOD

CAD

COD

d

DMRT

DO

DRC

HDPE

MLSS

OLR

PVC

RCCR

RSS

SS

SSA

TSS

UASB

UV

vsS
Anaerobic filters

Biological oxygen demand

Covered activated ditch system

Chemical oxygen demand

Day

Duncan multiple range test

Dissolved oxygen

Dry rubber content

High density polyethylene

Mixed liquor suspended solids

Organic loading rate

Poly vinyl chloride

Rubberized coir carrier reactor

Ribbed smoked sheet

Suspended solids

Specific surface area

Total suspended solids

Up-flow anaerobic sludge blanket

Ultra violet

Volatile suspended solids 


\title{
Effectiveness of coconut fibre media in biological wastewater treatment for rubber factory effluent
}

\section{Kudaligama Vithanage Vidya Sagari Kudaligama}

\begin{abstract}
The Central Environmental Authority of Sri Lanka has identified the natural rubber industry as one of the most significant water polluting industries in Sri Lanka and it discharge about 18 million $\mathrm{kg}$ of $\mathrm{COD}$ to the environment annually (Anon, 1992b). With the new legislations, almost all the rubber processing factories are faced with difficulties of finding out a suitable treatment for their factory effluent.
\end{abstract}

Maintaining an adequate amount of active biomass is the key to a safe, stable operation of a biological treatment system. Bio-brush media was developed to become a low cost media with all ideal characteristics that lead to a low cost anaerobic treatment system known as Covered Activated Ditch (CAD) system. Therefore, the main objective of this study was aimed to optimise the treatment efficiency of CAD systems by selecting the best packing strategy of Bio-brush medium.

Five $\left(50,100,150,200\right.$ and $\left.250 \mathrm{~m}^{2} / \mathrm{m}^{3}\right)$ and four $\left(25,50,75\right.$ and $\left.100 \mathrm{~m}^{2} / \mathrm{m}^{3}\right)$ specific surface areas (SSA) were set with $10 \mathrm{~cm}$ and $15 \mathrm{~cm}$ diameter Bio-brush media respectively and were subjected to run under four different organic loading rates $(0.5$, 
1.0, 2.5 and $3.5 \mathrm{CODkg} / \mathrm{m}^{3} / \mathrm{d}$ ). The reactors with the highest SSA always showed fast start-up and highest treatment efficiencies. At the same time $100 \mathrm{~m}^{2} / \mathrm{m}^{3} \mathrm{SSA}$ was set with three diameters $(5,10$ and $15 \mathrm{~cm})$ of Bio-brushes and run under the same organic loads introduced in the above, to see the effect of diameter of Bio-brush media on treatment efficiency.

When increasing the SSA of media, the COD removal efficiency increased under all four OLRs. The treatment efficiency of rectors decreased with increasing OLRs. COD removal efficiency increased when the diameter of the medium is increased except under $1.0 \mathrm{COD} \mathrm{kg} / \mathrm{m}^{3} / \mathrm{d}$ OLR. During this OLR the highest performance was shown by the Bio-brush media with $10 \mathrm{~cm}$ diameter.

With the results obtained, the reactor set with $200 \mathrm{~m}^{2} / \mathrm{m}^{3}$ SSA using $10 \mathrm{~cm}$ diameter Bio-brush media run under $1.0 \mathrm{CODkg} / \mathrm{m}^{3} / \mathrm{d}$ OLR was chosen as the best combination for rubber factory effluent treatment. COD, $\mathrm{pH}$ and $\mathrm{SS}$ of reactor with above combination was about $100 \mathrm{mg} / \mathrm{L}, 6.7$ - 7.2 and $26-43 \mathrm{mg} / \mathrm{L}$ (except in day 38) respectively after maturation and these values were within the maximum desirable levels stipulated by the Central Environmental Authority of Sri Lanka.

Nitrogen content of the effluent and the reactor $\mathrm{pH}$ affected the treatment efficiency. Chemicals, which were used during rubber processing also lowered the treatment efficiency. Long start-up periods observed during the treatment with higher organic loading rates could be lowered by $\mathrm{pH}$ correction of the reactors. Continuous removal of the suspended solids from the reactors avoids clogging of the reactors. 